\title{
POSSIBILITIES FOR THE DEVELOPMENT OF CREATIVE TOURISM BASED ON PODRAVINA'S NAIIVE ART HERITAGE
}

\author{
Rikard Bakan \\ Dejan Tubić \\ Helena Jošt
}

https://doi.org/10.20867/tosee.05.51

\begin{abstract}
Purpose - the main purpose of this work is to explore the possibility for the development of creative tourism based on the rich heritage of naïve art in Podravina.

Methodology - the literature research has produced a theoretical review and analysis of the phenomenon of creative tourism as a means for creating innovative tourism products that incite tourists to a complete immersion in the destination experience, which stands as the one of the main motives of modern tourist travels. In order to examine the possibilities for creative tourism development based on Podravina's naïve art heritage, the authors have conducted an attraction base and SWOT analysis as well as an in-depth interview with four destination stakeholders that are presumed to be the backbone for the development of future creative tourism products.

Findings - the data obtained through the analysis and the interview shows that there are several potential attractions as well as an incentive for creating the tourist supply that is based on the naïve art. However, there is no singular approach to the development of the destination tourism product nor to associating the stakeholders in creating a serious tourist supply and promoting the supply. Contribution - creative tourism based on the worldwide recognition of Podravina's naïve art demands a wider integral approach to planning and managing the destination tourism product, an association in terms of delivering singular creative tourist experiences, as well as the support of national institutions.
\end{abstract}

Keywords creative tourism, naïve art, experience tourism, Podravina

\section{INTRODUCTION}

Tourism is an exceptionally dynamic system that shows noticeable growth rates year after year - the growth that exceeds the forecasts emphasized in the UNWTO Tourism Towards 2030-Global Overview (UNWTO 2011, 10). In accordance with that, national tourism policies, as well as the strategies for the development of tourism at lower levels are continually being presented with new challenges. Due to the increased competition and tourist mobility on a global scale, as well as the availability of tourist destinations (physical, but even more informational) and in order to raise their competitiveness in the market, tourist destinations need to re-activate the inactive resources and methods for raising their competitiveness in the tourism market. The destination management is therefore presented with a task of an active and constant endeavour in creating innovative tourist experiences based on the key and unique components of the tourist attraction base that are the best indicators of the differentiation of a certain tourist destination in comparison to its competitors (Ritchie and Crouch, 2003, 9, UNWTO/ETC 2009, 41; 
ToSEE - Tourism in Southern and Eastern Europe, Vol. 5, pp. 47-59, 2019

R. Bakan, D. Tubić, H. Jošt: POSSIBILITIES FOR THE DEVELOPMENT OF CREATIVE TOURISM ...

Morgan and Prichard, 2004, 60). The trends visible in the market of tourist demand, especially the trends connected to the changes in the travelling preferences and motives of modern tourists indicate a shift from the interest for physical characteristics (tangible characteristics) of the destination and "the sight-seeing tourism" towards the interest in intangible characteristics of the destination and "the experience tourism" (Richards and Wilson 2007, 18, Richards 2012, 14). What attracts modern tourists into certain destinations is the desire for meeting the local culture and lifestyle, as well as unforgettable and authentic experiences. In other words, in the period of their vacation, the tourists have a desire to live - to a lesser or greater extent - as local inhabitants or as hosts in the facilities they are staying in (Aref et al 2010, Vrtiprah 2006, Expedia 2017, 12; IPSOS 2017, 19; Tripadvisor 2017, 14). Precisely such elements of experience, termed as the "Four Realms of Experience" by Pine and Gilmore (1999, 30), along with other "intangible" elements of the tourist products alike, present the strongest means for differentiating the destination supply due to the modern tourists' focus on experiences that encompass the elements of discovering the New and the Unknown, the elements that encompass entertainment, educational content and creativity, but also a relaxing atmosphere that completely contrasts with the atmosphere of life in their place of residence (UNWTO, 2015, 35). The trends alike were also recorded in Croatia, which is shown in a research made by the Institute for Tourism (Institute for Tourism 2008, 11), as well as in the work of the authors examining the phenomenon of cultural and creative tourism in Croatia (see especially Tomljenović 2006, Jelinčić 2008, Jelinčić 2009, Jelinčić and Žuvela 2012, Jelinčić and Senkić 2017). Croatian naïve art of the Podravina area, especially the art originating in Hlebine, is recognizable on a world scale and can thus present a powerful resource for creating innovative cultural and creative tourism products, especially since this special form of art draws its inspiration from the motives of villages and the lifestyle of Podravina's rural areas, and it can thus be connected with other cultural heritage attractions and the atmosphere of the rural area. The creation of an integral creative tourism product based on the motive of Podravina's naïve art could contribute to the recognition and originality of the tourist supply of Podravina and hence to the extension of tourist activities into the areas of Continental Croatia which are still insufficiently recognized. It is therefore the purpose of this work to examine the possibilities for creating original creative tourism products based on the rich heritage of Podravina's naïve art by means of an analysis of the tourist resource base and interviews with selected stakeholders in the destination.

\section{RAISING THE ATTRACTIVENESS OF TOURIST DESTINATIONS THROUGH THE DEVELOPMENT OF CREATIVE TOURISM}

\subsection{The growth of cultural tourism in the contemporary tourist environment}

The dynamic nature of tourism as the phenomenon of the $20^{\text {th }}$ century, as well as its constant growth in the current century is supported by the indicators of tourist visits on a global scale. According to the data by UNWTO, the amount of tourist travels has reached the total of 1,4 billion visits in 2018. This goal was reached two years prior to the forecasts made by UNWTO's long-term forecast issued in 2010 (UNWTO 2019, 1). Tourism is a mass phenomenon, but the term of mass tourism has evolved long ago. It is needless to say that the number of different motives that attract the tourists into a certain 
ToSEE - Tourism in Southern and Eastern Europe, Vol. 5, pp. 47-59, 2019

R. Bakan, D. Tubić, H. Jošt: POSSIBILITIES FOR THE DEVELOPMENT OF CREATIVE TOURISM ...

destination as well as the number of activities that these tourists want to experience during their travels, i.e. what the tourists want to experience, grows proportionally with the number of tourists. Mass tourism market has become exceptionally fragmented, which resulted in an array of different market niches. Cultural tourism has become one of the most significant niches (Richards 2014, 1). The OECD publication named The Impact of Culture on Tourism from the year 2009 emphasizes the factors on the side of the demand, as well as the factors on the side of the supply as the factors that are responsible for the growth of cultural tourism:

On demand side:

- Increased interest in culture, particularly as a source of identity and differentiation in the face of globalisation

- Growing levels of cultural capital, stimulated by rising education levels.

- Aging populations in developed regions

- Postmodern consumption styles, emphasising personal development rather than materialism.

- A desire for direct forms of experience ("life seeing" rather than sightseeing).

- Growing importance of intangible culture and the role of image and atmosphere.

- Increased mobility creating easier access to other cultures.

On supply side:

- Development of cultural tourism to stimulate jobs and income.

- Cultural tourism was seen as a growth market and "quality" tourism.

- An increasing supply of culture as a result of regional development.

- The growing accessibility of information on culture and tourism through new technologies.

- The emergence of new nations and regions eager to establish a distinct identity.

- A desire to project the external image of regions and nations.

- Cultural funding problems related to increasing cultural supply. (OECD 2009, 19 20).

The most recent UNWTO Report in Tourism and Culture Synergies also substantiates the importance of cultural tourism in the contemporary market. It is estimated that the amount of tourist visits motivated by culture and culture-related experiences has reached the share of $36 \%$ of the total tourist movements, which makes up the number of roughly 516 billion international tourist visits, and there are also some predictions of growth in the years that follow. In addition, $89 \%$ of the surveyed national tourist policy stakeholders among the members of the UNWTO (44\% of all members were surveyed), have indicated cultural tourism as an essential part of their tourist policies and strategies (UNWTO 2018). What is also quite remarkable is the fact that cultural tourism has slowly began to take on the characteristics of mass tourism and that it is also undergoing a certain evolution. Cultural tourism 2.0 where the supply was mostly the heritage-based product is beginning to shift towards cultural tourism 3.0 (Richards 2014b) where the tourists' interests and motives shift towards the intangible products and creative holidays as well as to the live-like-locals approach, which hence leads to the interconnection of tourists experiences with the everyday lifestyle of the destinations visited by the tourists. 
ToSEE - Tourism in Southern and Eastern Europe, Vol. 5, pp. 47-59, 2019

R. Bakan, D. Tubić, H. Jošt: POSSIBILITIES FOR THE DEVELOPMENT OF CREATIVE TOURISM ...

\subsection{From cultural toward creative tourism}

According to Richards (2005), the onsets of the concept of creative tourism can be traced back to the second half of the 90's when the European Commission sought to find ways to increase the sales of locally-produced produce in rural areas through a project named the EUROTEX project. Discussions with local craftsmen and tourists led to the conclusion that the majority of tourists were not only willing to buy crafts products, but they were also interested in seeing how this produce is made and in learning the skills for producing those products. The validity for taking a stand that creative tourism development require more investment can also be found in other works of the scientists form that period, primarily in the works of Jansen (1999) and Pine and Gilmore (1999), as well as the somewhat more recent work of Richard Florida "The Creative Class" from the year 2002. In the work, he emphasizes that the cheap raw materials or work are no longer sufficient for competitiveness on market, but that human creativity is becoming the main comparative advantage (Florida 2012, 30). The concept of the experience economy, placed in the midst of the interest of the business and scientific community at the end of the last century by Pine and Gilmore (1998, 1999), is not an entirely new theory. This term was first introduced by Alvin Toffler (1970) in his work Future Shock (1982). Subsequently, the term was further analysed and corroborated by Holbrook and Hirschmann (1982), and that is as an already existing model for achieving a certain business subjects' competitive advantages in the market (Jelinčić and Šikić, 2017, 114). Around the same time, there came to the emergence of Rolf Jansen's book "The Dream Society", which describes the evolution of the economy from an agricultural towards the informational society and ultimately towards the Dream Society, the society with the post-materialistic demand at work, with pictures, stories, myths and legends as main features of the demand and the storytelling as a means for creating new economic values (Jansen 1999, 34). All of the above-mentioned facts indicate that the way for reaching and surpassing the tourists' expectations in the contemporary tourism market is becoming increasingly dependent on the method by which the tourist destination uses its cultural heritage - the tangible one, but even more the intangible one - as a resource for developing recognizable and innovative tourist products thus complementing other elements of tourist attractiveness (Jelinčić and Šikić 2017, 110). By definition, the intangible cultural heritage encompasses mainly those "intangible experience elements" which, judging by the preferences of the majority of modern tourists, present precisely those elements of the supply that have the greatest contribution on the authenticity and differentiation of certain tourist destinations and, based on the motives of a certain tourist segment, a crucial role in deciding on the choice of the travel destination (Binkhorst and Den Deckker 2009, 313). The above-mentioned facts also confirm the growing interest for the tourist experiences of cultural tourism, especially creative tourism, as well as the indicators that show a growth in the number of culture-motivated travels and creative vacations on a global scale (OECD 2009, 21, Richards 2014a, 2). The growth of creativity also initiates the concentration of creative industries in certain cities or areas. Such areas exude a special atmosphere, openness and creative environment, so many of the destinations alike begin to attract the tourists. For that reason, the destination management strives to create new tourist products and to complement the existing ones by giving prominence to local heritage such art, music, gastronomy... (Richards and Wilson 2006, 17). The growth in the prominence of creative industries can be traced along with the development of the experience economy as a new economic paradigm 
ToSEE - Tourism in Southern and Eastern Europe, Vol. 5, pp. 47-59, 2019

R. Bakan, D. Tubić, H. Jošt: POSSIBILITIES FOR THE DEVELOPMENT OF CREATIVE TOURISM ...

(Pine and Gilmore, 1999, 22). However, due to the increased market competitiveness, even the experiences can be copied mainly in the elements of fun and aesthetics which were the main assets for experience staging in the mentioned period. Boswijk, Thijssen and Peelen label such experiences as "First generation experiences" and emphasize that the "second generation experiences" need to be based on the co-creation of experiences and the personalization of products and services by giving prominence to the individual users' characteristics, i.e. their personalities (Boswijk et al. 2007, 156). Pine and Gilmore also claim that the next phase of the economic development will see the phenomenon of staging experiences replacing the guiding transformation, i.e. the "transformationalexperiences" with the goal of changing the tourists themselves (Pine and Gilmore 2011, 244). Therefore, the elements that needs to be put into focus while creating new tourist products rest in the fact that the tourists need to be provided with the co-creation of experiences and the release of their own creativity (Tan et al 2013, 156). The increase in the importance of the current form of creative tourism lies in many reasons, among others in the following:

- Cultural tourism is becoming mass tourism

- Cultural tourists are becoming more experienced and demanding more engaging experiences

- Destinations are looking for alternatives to traditional tourism products

- Creativity creates 'atmosphere'

- Creativity feeds on people's need for self-development

- Creativity creates a direct link between the culture of the tourist and the host population

- Creativity avoids problems of heritage burnout and serial reproduction (Richards 2009, 85)

\section{PODRAVINA'S NAÏVE ART AS A RESOURCE FOR THE DEVELOPMENT OF CREATIVE TOURISM}

The naivë art emerged on the Croatian art scene in the year 1931 when the academic painter Krsto Hegedušić recognized and summoned the painters - farmers from Hlebine and other surrounding areas in Podravina - to exhibit their works in the third art exhibit of the group Earth. These were the painters Ivan Generalic and Franjo Mraz from Hlebine, somewhat later Mirko Virius from Đelekovec and the sculptor Petar Smaić from the Split area. In Croatia, the term naïve art signifies the artistic work of amateur artists, more or less self-taught authors, who never attended an art academy or any other art school (Crnković, 2000). The motives of the Croatian naïve art stem from the artistic fascination of common villagers and farmers and their love for landscapes, nature, forests, plains and hills of the Podravina area, but also for the lifestyle of rural communities (Jalšić Ernečić, 2010). According to Hegedušić, the art needed to correspond with the area where it was created. The paintings that were created in the manner of Croatian naïve art hence show the rural, undeveloped environment without any beautification and Generalić's style of painting distinctive for the portrayal of deformities and inelegance of his characters would soon become a recognizable phenomenon of Croatian naïve art (Kušenić 2018). The fact that Ivan Generalić exhibited his works in Paris in 1953, Sao Paolo in 1956 and Brussels in 1958 also signifies the 
ToSEE - Tourism in Southern and Eastern Europe, Vol. 5, pp. 47-59, 2019

R. Bakan, D. Tubić, H. Jošt: POSSIBILITIES FOR THE DEVELOPMENT OF CREATIVE TOURISM ...

recognition of Podravina's naïve art on a global scale. Although Ivan Rabuzin did not belong to the group of Podravina's naïve artists, they served him as role models and his works were inspired by the same motives. The curtains painted by Ivan Rabuzin adorn a theatre in Tokyo and the Okawa Museum of Modern Art. He was also the only person after Vasarely and Rousseau who painted the ceramics of the internationally-renowned ceramic producer Rosenthal.

The Gallery of Naïve Art in Hlebine was opened in 1967 and due to its art exhibits, as well as its architecture and its special layout, it was already obvious that it should not only be a classic gallery space but also a tourist attraction (Š́poljar 1996). In the second half of the $20^{\text {th }}$ century, The Gallery gained some additional content, the Sculpture Park in 1974 and in 1985 an annex with works of Ivan Generalić. Hlebine is also home to the Gallery of Josip Generalić as a separate complex consisting of Ivan Generalić's old house, the atelier of his son Josip Generalic and an ethnological house with an ethnological collection of work objects from the area of Hlebine.

\subsection{Methodology and interpretation of results}

In order to examine the possibilities for the development of creative tourism in the area of Hlebine and the surrounding areas of Podravina, the authors of this work have conducted an analysis of the tourist attraction base according to the methodology proposed by Kušen (Kušen 2002, 67-141) with the primary focus on the attractions of cultural and historical heritage, as well as the culture of life and work of that area. In addition, the authors have conducted in-depth interviews by a deliberate selection method with four stakeholders that were considered as key interlocutors based on the topic of the research but also as future holders of the initiative for the development of the creative tourism of the researched area. The interlocutors in the mentioned interviews were the curator of the Koprivnica Town Museum Helena Kušenić, Ivan Generalić Junior a student on Faculty of Tourism and Hospitality Management and one of the owner of Josip Generalić Gallery, a traditional craftsman Tihomir Želimorski - the owner of the Old Crafts trade which encompasses a studio apartment, and a sixtyoneyear-old naïve painter and disciple of Ivan Generalić, Željko Kolarek from Hlebine. The interviews were conducted during the month of November 2018. The questions were based on the analysis of the tourist attraction base of Hlebine that was previously made by the authors of this work. The goal of the interviews was to gain the interlocutors' opinions on the estimation of the destination's attractivity for the development of creative tourism, the current state of tourism of this area, the existent tourist products and the initiatives for the development of tourism, as well as on the deficiencies, threats, opportunities and the strengths that Hlebine disposes of as a tourist destination.

Table 1 on the following pages show a part of the tourist attraction base of Hlebine, i.e. the cadastre cards of the tourist attractions connected to the cultural and historical heritage and the culture of life and work. The data show that the examined area holds several key tourist attractions of an international and national importance with a fairly big visitation capacity and a solid tourist inventory with the possibility of a year-long visitation, as well as a good location and traffic connectedness with larger emissive areas and the possibility of interconnection with a broader system of attractions of the surrounding areas. According to the promotional materials of the County Tourist board, 
ToSEE - Tourism in Southern and Eastern Europe, Vol. 5, pp. 47-59, 2019

R. Bakan, D. Tubić, H. Jošt: POSSIBILITIES FOR THE DEVELOPMENT OF CREATIVE TOURISM ...

there is the Gallery Road that connects around fifteen galleries and a few ethnographic collections in the county of Koprivnica-Križevci and precisely the galleries in Hlebine, being the birthplace of the Croatian naïve art, are indicated as its main and most recognizable points. Unfortunately, this product has still not gained any market prominence as a tourist experience, but it could be used as the grounds for the creation of an integral tourism product with the main motive, i.e. the brand of Podravina's naïve art as the backbone of the future destination product of creative tourism. The Gallery of Naïve Art and the Gallery of Josip Generalić must certainly be put into foreground, since they are already almost fully equipped not only as museum facilities but also as tourist attractions that have a great potential of becoming the central areas of creative tourist experiences. Naïve art can certainly become the central motive for building different experiences of cultural and creative tourism. For several years now, according to the curator Kušenić, the Koprivnica Town Museum organizes a three-day week-end event called KUL Hlebine which includes the accommodation in Hlebine by camping in the gallery yard, workshops on naïve art, the interpretation of local stories and legends, as well as several activities in the nature. However, this event is currently focused only on one narrow segment, i.e. on school children aged from 8 to 12 years.

\section{Table 1: Attraction cadaster card}

\begin{tabular}{|l|l|l|}
\hline $\mathbf{1}$ & Number & 1 \\
\hline $\mathbf{2}$ & Attraction & Naive art gallery \\
\hline $\mathbf{3}$ & Short description & $\begin{array}{l}\text { Main tourist attraction. Home of most famous pieces of } \\
\text { Croatian naïve art; exhibitions; anniversaries, wide open } \\
\text { courtyard with sculpture exhibition and space suitable for } \\
\text { camping and open-air activities. }\end{array}$ \\
\hline $\mathbf{4}$ & Location & $\begin{array}{l}\text { About 90 kilometers from Zagreb, 51 kilometers from } \\
\text { Varaždin, 14 km from Koprivnica and from Đurđevac 15 } \\
\text { kilometers away by public roads. }\end{array}$ \\
\hline $\mathbf{5}$ & Category & International \\
\hline $\mathbf{6}$ & Excursion Features & $\begin{array}{l}\text { Present: for one day visitors mostly } \\
\text { Future: center for creative experiences }\end{array}$ \\
\hline $\mathbf{7}$ & Seasonality & Year-long \\
\hline $\mathbf{8}$ & Capacity & 100 visitors at the same time, 1000 per day \\
\hline $\mathbf{9}$ & Wider Attraction area & Podravina and Prigorje Gallery roads \\
\hline
\end{tabular}


ToSEE - Tourism in Southern and Eastern Europe, Vol. 5, pp. 47-59, 2019

R. Bakan, D. Tubić, H. Jošt: POSSIBILITIES FOR THE DEVELOPMENT OF CREATIVE TOURISM ...

\begin{tabular}{|l|l|l|}
\hline $\mathbf{1}$ & Number & 2 \\
\hline $\mathbf{2}$ & Attraction & Gallery Josip Generalić \\
\hline $\mathbf{3}$ & Short description & $\begin{array}{l}\text { Spatially and thematically, it relies on the Old House of Ivan } \\
\text { Generalić, and features a selection of works from the rich opus } \\
\text { of Josip Generalić: oil on glass and canvas, watercolors and } \\
\text { prints, an ethnological house and wide open yard with an Ivan } \\
\text { Generalić's orchard }\end{array}$ \\
\hline $\mathbf{4}$ & Location & $\begin{array}{l}\text { About 90 kilometers from Zagreb, 51 kilometers from } \\
\text { Varaždin, 14 km from Koprivnica and from Đurđevac 15 } \\
\text { kilometers away by public roads.. }\end{array}$ \\
\hline $\mathbf{5}$ & Category & National \\
\hline $\mathbf{6}$ & Excursion Features & $\begin{array}{l}\text { Present: for one day visitors mostly } \\
\text { Future: center for creative experiences }\end{array}$ \\
\hline $\mathbf{7}$ & Seasonality & Year-long \\
\hline $\mathbf{8}$ & Capacity & W0 visitors at the same time, 500 per day \\
\hline $\mathbf{9}$ & Wider Attraction area & Podravina and Prigorje Gallery roads \\
\hline
\end{tabular}

\begin{tabular}{|l|l|l|}
\hline $\mathbf{1}$ & Number & 3 \\
\hline $\mathbf{2}$ & Attraction & Crafts and accommodation facility Želimorski \\
\hline $\mathbf{3}$ & Short description & $\begin{array}{l}\text { The primary offer is for children mainly but it also may be } \\
\text { suitable for other segments of tourists. Craft production and } \\
\text { workshop experience, craft and gastro exhibitions }\end{array}$ \\
\hline $\mathbf{4}$ & Location & $\begin{array}{l}\text { About } 90 \text { kilometers from Zagreb, 51 kilometers from } \\
\text { Varaždin, 14 km from Koprivnica and from Đurđevac 15 } \\
\text { kilometers away by public roads. }\end{array}$ \\
\hline $\mathbf{5}$ & Category & Regional \\
\hline $\mathbf{6}$ & Excursion Features & For visitation and logging through the week-end \\
\hline $\mathbf{7}$ & Seasonality & Year-long \\
\hline $\mathbf{8}$ & Capacity & Accommodation for four persons \\
\hline $\mathbf{9}$ & Wider Attraction area & Traditional logging of Podravina, traditional craft production \\
\hline
\end{tabular}

\begin{tabular}{|l|l|l|}
\hline $\mathbf{1}$ & Number & 4 \\
\hline $\mathbf{2}$ & Attraction & KUL Hlebine \\
\hline $\mathbf{3}$ & Short description & $\begin{array}{l}\text { KUL Hlebine (Culture, Art, Logging) is the name of a three- } \\
\text { day camp. In the backbone of the campus someone can learn } \\
\text { paint on glass, as well as getting acquainted with the spatial } \\
\text { and social context that has led to naive art }\end{array}$ \\
\hline $\mathbf{4}$ & Location & $\begin{array}{l}\text { About 90 kilometers from Zagreb, 51 kilometers from } \\
\text { Varaždin, 14 km from Koprivnica and from Đurđevac 15 } \\
\text { kilometers away by public roads. }\end{array}$ \\
\hline $\mathbf{5}$ & Category & Regional with potential of national significance \\
\hline $\mathbf{6}$ & Excurison Features & week-end experience \\
\hline $\mathbf{7}$ & Seasonality & From May till September \\
\hline $\mathbf{8}$ & Capacity & Tents for about 20 children \\
\hline $\mathbf{9}$ & Wider Attraction area & Craoatian schools in nature network \\
\hline
\end{tabular}

Source: authors 
ToSEE - Tourism in Southern and Eastern Europe, Vol. 5, pp. 47-59, 2019

R. Bakan, D. Tubić, H. Jošt: POSSIBILITIES FOR THE DEVELOPMENT OF CREATIVE TOURISM ...

The property of Tihomir Želimorski is also visited mostly by school children, but the establishment of accommodation capacities (although with only a minimal number of four beds) has also led to the beginning of visitations by adult visitors. Ivan Generalic indicates that the majority of the tourist visits are still focused mainly on the mentioned two galleries. These are mostly one-day visits organized by tourist agencies that organize tourist excursions in the wider area of Podravina. Ivan Generalić also emphasizes that the more serious development of tourism in Hlebine requires more catering, accommodation and other tourist facilities but more so an organized and planned management of the destination tourism product as well as the interconnection with other stakeholders not only in Hlebine, but also in the neighboring destinations such as Koprivnica and Đurđevac. Željko Kolarek recalls the 80's when the "buzz" around the naïve art of Podravina was fairly more prominent and that in these years Hlebine had a greater number of tourist visits than nowadays. He also adds that he is aware of the fact that the galleries themselves cannot be enough for a more serious tourist offer, especially if the guests wish to spend several days in the destination, but he also emphasizes that the Hlebine's naïve art still stands as strong brand for creating original products of creative tourism. He sees the living artists of the $2^{\text {nd }}$ generation of the Hlebine School and the current artists as having a special role and serving as the best interpreters and demonstrators of the world-known technique of reverse glass painting. The property of Tihomir Želimorski, opened in 2018, also serves as a great example of positive thinking in terms of developing the tourist offer with distinctive local features. The property is based on the concept of providing the guests with creative time-spending opportunities with the possibility of workshops for creating wooden toys, as well as pottery and blacksmithing workshops. There is also an interesting corn labyrint on the property which is currently intended only for school-aged children.

\section{Table 2: SWOT analysis of Hlebine destination}

\begin{tabular}{|c|c|}
\hline STRENGTHS & NESESS \\
\hline 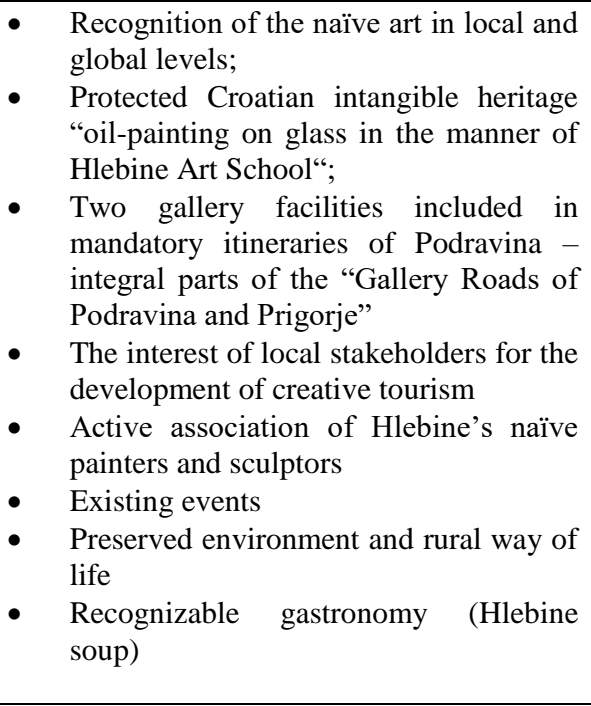 & $\begin{array}{l}\text { - Lack of policy planning and tourism } \\
\text { development strategy in the municipal } \\
\text { area } \\
\text { - Stakeholders Business Connections are } \\
\text { insufficient } \\
\text { - Lack of entrepreneurial initiative } \\
\text { - Small range of accommodation and } \\
\text { catering facilities } \\
\text { Insufficient kowledge of the local } \\
\text { population on the benefits of tourism } \\
\text { development } \\
\text { 59\% of the population are not using the } \\
\text { Internet } \\
\text { Insufficient budgeting of the } \\
\text { municipality to support tourism } \\
\text { development } \\
\text { Unexperienced personnel for better use } \\
\text { of support from national and European } \\
\text { funds }\end{array}$ \\
\hline
\end{tabular}


ToSEE - Tourism in Southern and Eastern Europe, Vol. 5, pp. 47-59, 2019

\begin{tabular}{|c|c|}
\hline OPPORTUNITIES & THREATS \\
\hline $\begin{array}{l}\text { - Activities of the Koprivnica -Križevci } \\
\text { Tourist Board and Association of } \\
\text { Hlebine's Naïve Painters on further } \\
\text { promotion of Naive Art in Europe and } \\
\text { the World through the "Easter Egg from } \\
\text { the hart" and Similar Projects with wider } \\
\text { Institutional Support } \\
\text { Nearby international cyclotourist route } \\
\text { of EUROVELO } 13 \text { and the possibilities } \\
\text { for integration of creative tourism with } \\
\text { gastroturism, cyclotourism and other } \\
\text { forms of nature-based tourism } \\
\text { Additional investment in gallery spaces } \\
\text { and establishment of the Cultural Center } \\
\text { in Hlebine } \\
\text { Creating a cluster for creative tourism } \\
\text { development and IQM with recognizable } \\
\text { identity of Podravina naïve } \\
\text { Education to enhance awareness of the } \\
\text { local population about the importance of } \\
\text { tourism development } \\
\text { Better use of EU funds and other } \\
\text { measures to stimulate investment in } \\
\text { enrichment of tourist infrastructure } \\
\text { Increasing public interest at national } \\
\text { level towards initiatives for the } \\
\text { development of innovative tourist } \\
\text { products in continental Croatia } \\
\text { Strengthening the activities of the } \\
\text { Tourist board of Central Podravina }\end{array}$ & 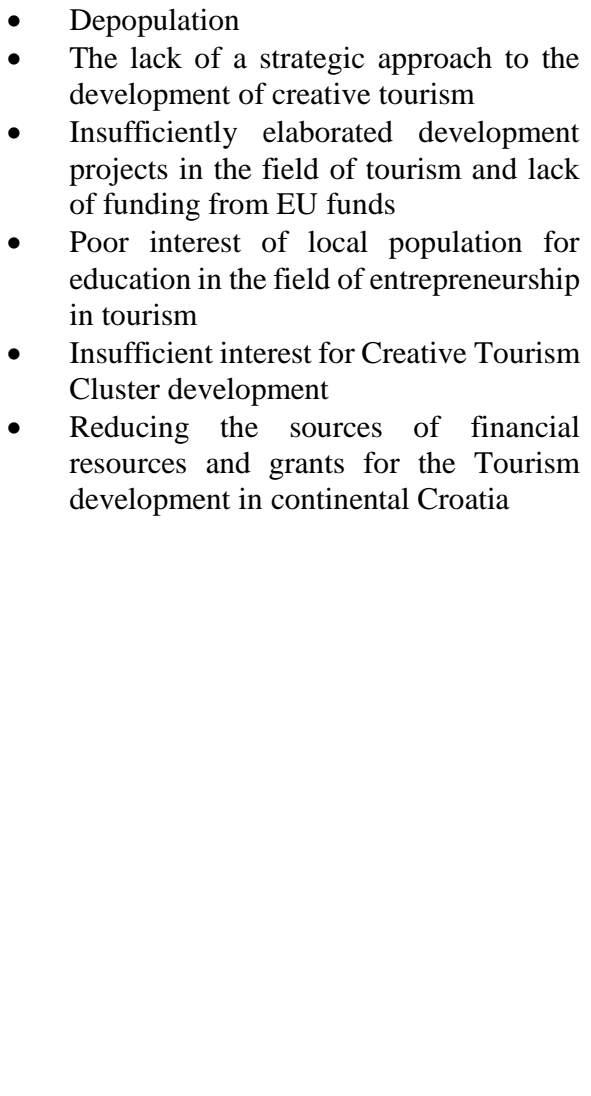 \\
\hline
\end{tabular}

Source: authors according to answers of respondents

\section{FINAL CONSIDERATIONS AND CONCLUSION}

The literature research has produced a theoretical review and analysis of the phenomenon of creative tourism as a means for creating innovative tourism products that incite tourists to a complete immersion in the destination experience, which stands as the one of the main motives of modern tourist travels. Podravina's naïve art, the authenticity of art creation based on local motives and lifestyle can be a strong means for the development of this special form of tourism in Hlebine and Podravina itself. Empirical research, i.e. the analysis of the tourist attraction base, the interviews with the stakeholders and the SWOT analysis have shown that there is a very strong attraction base, as well as the strength, the opportunities and the willingness of the stakeholders for the development of this form of tourism. What also speaks in favour of Hlebine and its area as a rural destination with great possibilities for the development of creative tourism can be found in Richards and Wilson's work "Developing creativity in tourist experiences: A solution to the serial reproduction of culture? They claim that many good examples of creative tourism can nowadays be found in rural areas with a reduced possibility for the 
ToSEE - Tourism in Southern and Eastern Europe, Vol. 5, pp. 47-59, 2019

R. Bakan, D. Tubić, H. Jošt: POSSIBILITIES FOR THE DEVELOPMENT OF CREATIVE TOURISM ...

development of the offer of "classic" cultural tourism (Richards and Wilson 2006, 1218) but they also claim that precisely that fact could present the greatest comparative advantage of such destinations since they not only depicture the way of life and work, but they also exude the lifestyle, the atmosphere and the uniqueness that incites the creativity among the locals, as well as their guests. In Table 3, the characteristics of creative tourism according to Richards and Wilson are complemented with the advantages of the possible tourist offer that were noticed in Hlebine.

Table 3: Hlebine attractions fitting to the Creative tourism characteristics

\begin{tabular}{|c|c|c|c|}
\hline Primary time focus & Primary cultural focus & $\begin{array}{l}\text { Primary } \\
\text { consumption focus }\end{array}$ & $\begin{array}{l}\text { Primary learning } \\
\text { focus }\end{array}$ \\
\hline $\begin{array}{l}\text { Past: } \\
\text { - Galleries with } \\
\text { the works of } \\
\text { the pioneers of } \\
\text { Croatian naïve } \\
\text { art }\end{array}$ & \multirow{3}{*}{ 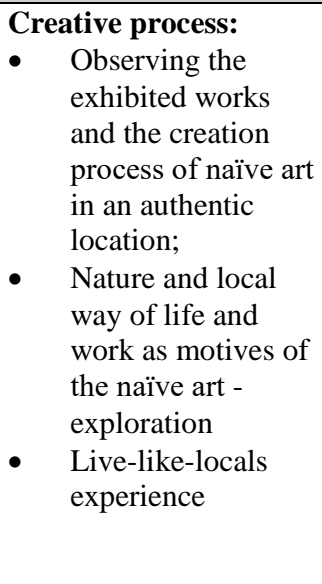 } & \multirow{3}{*}{$\begin{array}{l}\text { Experience, co- } \\
\text { makership: } \\
\text { - } \text { Tailor made } \\
\text { creative } \\
\text { products, } \\
\text { combination } \\
\text { element of } \\
\text { creative } \\
\text { tourism, } \\
\text { gastronomy } \\
\text { tourism and } \\
\text { nature-based } \\
\text { tourism }\end{array}$} & \multirow{3}{*}{$\begin{array}{l}\text { Active skill } \\
\text { development : } \\
\text { - Art schools } \\
\text { in the manner } \\
\text { of Hlebine } \\
\text { method } \\
\text { - Workshops } \\
\text { for creating } \\
\text { wooden toys, } \\
\text { pottery and } \\
\text { blacksmith } \\
\text { products }\end{array}$} \\
\hline $\begin{array}{l}\text { Present: } \\
\text { - } \quad \text { Living naïve } \\
\text { artists of } \\
\text { Hlebine }\end{array}$ & & & \\
\hline $\begin{array}{l}\text { Future: } \\
\text { - } \quad \text { Hlebine Art } \\
\text { School - } \\
\text { Creative and } \\
\text { co-creation } \\
\text { experience }\end{array}$ & & & \\
\hline
\end{tabular}

Source: authors according to Richards and Wilson $(2006,1217)$

Although it is evident that the examined destination possesses a great number of attractions for the development of original products of creative tourism and that the main attractions are still being visited, the development of a more serious and competitive destination product requires a wider integral approach to the development of the tourist offer, as well as the cooperation, the interconnection and the institutional help of the county of Koprivnica-Križevci, but also the help of the holders of tourist policies in higher levels. All four interviewed interlocutors have pointed out the mentioned facts as the main limiting factors for the underdevelopment of the destination's tourist offer. The lack of accommodation and catering facilities, indicated as another limiting factor by the interlocutors could (and should) be annulled by connecting with the neighbouring destinations, the towns of Koprivnica and Đurđevac that hold a greater number of accommodation capacities with an already quite poor number of tourist visits. In the OECD report Tourism and creative economy (OECD 2014, 87) it has been stated that creative storytelling for selling the stories and communicating local characteristics and authenticity to the visitors/tourists can be used more effectively under a strong, recognisable common brand. Aside of that it's important to point that a successful tourist destination also requires a well-conceptualized and integral system of managing the destination tourist offer, so in the future it will be necessary to research a wider approach for connecting Podravina Naïve art as a motive for branding as well as a tool for 
ToSEE - Tourism in Southern and Eastern Europe, Vol. 5, pp. 47-59, 2019

R. Bakan, D. Tubić, H. Jošt: POSSIBILITIES FOR THE DEVELOPMENT OF CREATIVE TOURISM ...

developing creative tourism products in all neighboring destinations in a manner of establishing certain cluster for creative experiences in Podravina.

\section{REFERENCES}

Aref, F. Gill, S.S. and Aref, F. (2010), "Tourism development in local communities: As a community development approach", Journal of American Science, Vol. 6, No. 2, pp. 155-161.

Binkhorst E. and Teun Den Dekker (2009), "Agenda for Co-Creation Tourism Experience Research", Journal of Hospitality Marketing \& Management, Vol. 18, No. 2-3, pp. 311-327, DOI:10.1080/19368620802594193

Boswijk, A., Thijssen, T. \& Peelen, E. (2007), The experience economy, a new perspective, Pearson Education Benelux, Amsterdam.

Crnković, V. (2000), Muzej hrvatske naivne umjetnosti, Zagreb

Expedia Media Solutions (2017), European travel and tourism trends research - Travel habits, behaviors, and influencers of British, German, and French travellers, pp. 12 https://info.advertising.expedia.com/european-travel-and-tourism-trends-for-german-britishfrench-travellers

Florida, R. (2014), The rise of the creative class-revisited: Revised and expanded, Basic Books (AZ).

http://www2.unwto.org/publication/unwto-world-tourism-barometer-and-statistical-annex-january-2019

http://www.iztzg.hr/UserFiles/File/novosti/2009_TOMAS_Kulturni_turizam_2008_Sazetak_i_Prezentacija.p df

IPSOS/EUROPE Assistance Survey (2017), Summer Holiday Plans among Europeans and Americans 17th Edition, pp. 19 https://www.ipsos.com/sites/default/files/2017-05/Ipsos_Europ_Assistance_Barometre-2017.pdf

Jensen, R. (1996), “The dream society”, Futurist, Vol. 30, No. 3, pp. 9-13.

Jelinčić, D.A. (2008), Abeceda kulturnog turizma, Izdavački savjet, 527.

Jelinčić, A.D. (2009), "Kulturni turizam: stanje i perspektive razvoja u Republici Hrvatskoj”, Zaštita okoliša $i$ regionalni razvoj - iskustva i perspektive, Tišma, S., Maleković, S. (ur.), Institut za međunarodne odnose, Zagreb, pp. 335-347.

Jelincic, D.A. and Zuvela, A.(2012), "Facing the challenge? Creative tourism in Croatia", Journal of Tourism Consumption and Practice, Vol. 4, No. 2, pp. 78-90.

Jelinčić, D.A., \& Senkić, M. (2017), "Creating a heritage tourism experience. The power of the senses", Etnološka tribina: Godišnjak Hrvatskog etnološkog društva, 47(40), pp. 109-126.

Jalšić Ernečić, D. (2010), Podravina, Koprivnica, Muzej Grada Koprivnice.

Kušen, E. (2002), Turistička atrakcijska osnova, Institut za turizam, Zagreb.

Kušenić, H. (2018), Putevima Hlebinske škole, Koprivnica, Muzej Grada Koprivnice.

Morgan N., Prichard A. (2004), "Meeting the destination branding challenge", in: Morgan N., Prichard A. and Pride R. (ed)., Destination branding: Creating the Unique Destination Proposition, Elsevier, Butterworth-Heinemann, Oxford, pp. 59-78.

OECD (2009), The Impact of culture on tourism, OECD Publishing.

OECD (2014), Tourism and the Creative Economy, OECD Studies on Tourism, OECD Publishing. http://dx.doi.org/10.1787/9789264207875-en

Pine, B.J. \& Gilmore, J.H. (1998), "Welcome to the experience economy", Harvard business review, 76, pp. 97-105

Pine, B.J.II. and Gilmore, J.H. (1999), The Experience Economy: Work is Theater and Every Business is a Stage, Harvard Business School Press, Boston, MA, USA.

Pine, B.J.II. and Gilmore, J.H. (2011), The Experience Economy, Updated edition, Harvard Business Review Press, Boston, MA, USA.

Richards, G. (2012), An Overview of food and tourism trends and policies in OECD Food and tourism experience: The OECD-Korea Workshop, OECD Studies on Tourism, OECD Publishing, pp. 1343.

Richards, G. (2014a), Tourism trends: The convergence of culture and tourism. The Netherlands: Academy for Leisure NHTV University of Applied Sciences.

Richards, G. (2014b), “Cultural Tourism 3.0. The Future of Urban Tourism in Europe?”, in: Garibaldi, R. (ed.), Il turismo culturale europeo, pp. 25-38.

Richards, G. \& Wilson, J. (Eds.). (2007), Tourism, creativity and development, Vol. 10, Routledge. 
ToSEE - Tourism in Southern and Eastern Europe, Vol. 5, pp. 47-59, 2019

R. Bakan, D. Tubić, H. Jošt: POSSIBILITIES FOR THE DEVELOPMENT OF CREATIVE TOURISM ...

Richards, G. \& Wilson, J. (2006), "Developing creativity in tourist experiences: A solution to the serial reproduction of culture?", Tourism management, Vol. 27, No. 6, pp. 1209-1223. DOI: 10.1016/j.tourman.2005.06.002

Richards, G. (2005), "Creativity: A new strategic resource for tourism", in Swarbrooke, J., Smith, M. \& Onderwater, L. (Eds.), Tourism, creativity and development: ATLAS Reflections, Association forTourism and Leisure Education, Arnhem, pp. 11-22.

Richards, G. (2009), "Creative tourism and local development", in: Wurzburger, R., Pattakos, A. and Pratt, S. (eds) Creative Tourism: A global conversation, Sunstone Press, Santa Fe, pp. 78-90.

Ritchie, J.R.B. and Crouch, G.I. (2003), The Competitive Destination - A Sustainable Tourism Perspective, CABI Publishing, Wallingford.

Špoljar, M. (1996), Hlebine u srcu, Koprivnica.

Tan, S.K., Kung, S.F. \& Luh, D.B. (2013), “A model of 'creative experience'in creative tourism”, Annals of tourism research, 41, pp. 153-174. http://dx.doi.org/10.1016/j.annals.2012.12.002

Tomljenović, R. (2006), Hrvatski turizam-plavo, bijelo, zeleno: Kulturni turizam, Institut za turizam, Zagreb.

Tripadvisor (2017), TripBarometer-Travel Trends 2016. pp. 14, https://www.tripadvisor.com/TripAdvisorInsights/wp-content/uploads/2018/01/Global-ReportUS-Travel-Trends-TripBarometer-2016.pdf,

UNWTO (2011), Tourism Towards 2030/Global Overwiev, World Tourism Organisation, Madrid.

UNWTO/ETC (2009), A handbook on tourism destination branding with introduction by Simon Anholdt, UNWTO/ETC.

World Tourism Organization (2015), Affiliate Members Global Reports, Volume twelve - Cultural Routes and Itineraries, UNWTO, Madrid. https://www.e-unwto.org/doi/book/10.18111/9789284417704

World Tourism Organization (2018), Tourism and Culture Synergies, UNWTO, Madrid, DOI: https://doi.org/10.18111/9789284418978

Rikard Bakan, MB Econ. Senior Lecturer

Virovitica College,

Department for tourism

M.Gupca 78, Virovitica, Croatia

Phone: +38533492 274

E-mail: rikard.bakan@vsmti.hr

Dejan Tubić, PhD, Lecturer

Virovitica College,

Department for tourism

M.Gupca 78, Virovitica, Croatia

Phone: +38533492261

E-mail: dejan.tubic@vsmti.hr

Helena Jošt, struč.spec.oec.

Virovitica College,

M.Gupca 78, Virovitica, Croatia

Phone: +385 92235731

E-mail: helenajostkc@gmail.com 